\title{
Effect of Some Cultural Practices on Shedding and Yield of Egyptian Cotton
}

Elhamamsey, M.H. ${ }^{2}$; E.M, Shalaby ${ }^{1}$; EA. Ali $^{1}$ and M.A. Emara ${ }^{2}$

${ }^{1}$ Department of Agron., Fac. of Agric., Assiut Univ.

${ }^{2}$ Department of Agron., Cotton Res. Inst., Agric. Res. Center.

Received on: $12 / 5 / 2016$

Accepted for publication on: 26/5/2016

\begin{abstract}
Two field experiments were carried out in Shandaweel Agric. Res. Sta., Agric. Res. Centre, Sohage Governorate, Egypt during 2014 and 2015 seasons to study the effect of planting dates, i.e. $20^{\text {th }}$ March and $20^{\text {th }}$ April, fertilization rates of nitrogen and potassium with application of micronutrients as foliar spray and splitting fertilizerson shedding, yield and its attributes of Giza 90 cotton cultivar. In each season, separate trial was conducted for each planting date and the combinations between fertilization rates and splitting fertilizers rates (12 treatments) were arranged in a split plot design with 4 replicates. The combined analysis was carried out for the collected data from the two planting dates in each year using MSTAT software.
\end{abstract}

The results obtained could be summarized as follows:

1. Shedding $\%$ in squares and bolls increased with delaying planting date. Higher rate of fertilization led to increase the shedding of floral buds but decreased the shedding of bolls. Fertilizers splitting led to a significant increase in squares shedding $\%$ while, decreased boll shedding $\%$.

2. Maximum number of squares/plant, number of flowers/plant, number of bolls/plant, boll weight and seed cotton yield/fed, were reacted significantly to planting date in the two growing seasons in favor of early planting.

3. Among fertilization rates, maximum number of squares/plant, number of flowers/plant, number of bolls/plant, boll weight and seed cotton yield /fed were recorded with using of high fertilizer rates, i.e. $70 \mathrm{~kg} \mathrm{~N}+36 \mathrm{kgK}_{2} \mathrm{O}$. Micronutrients spray failed to appear any effect on most of studied traits.

4. Maximum number of squares/plant, number of flowers/plant, number of bolls/plant, boll weight and seed cotton yield/fed were obtained with splitting of fertilization rates to 4 equal partitions, compared with splitting of fertilization rates to 3 or 2 equal partitions.

5. Generally, the obtained results revealed that the cotton should be sown early. High rates of fertilizer, i.e. $70 \mathrm{~kg} \mathrm{~N}+36 \mathrm{~kg} \mathrm{~K} \mathrm{~K}_{2} \mathrm{O}$ with splitting it to four equal doses is a must for obtaining high productivity of cotton (Giza 90 variety) under the conditions of Shandaweel district.

Keywords: Cotton, Sowing Date, Shedding, Fertilization, Fertilizers Splitting, Micronutrientand Yield.

\section{Introduction}

Shedding in cotton either in squares or bolls is very important in determining yield of seed cotton per unit area. Maintaining one square on the plant represents one kantar of cot- ton. Abscission of squares and young bolls is a natural occurrence in cotton that is affected by adverse environmental conditions including extreme temperatures and the imbalance of nutrients. Some researchers regard to 
shedding as a disorder that, if corrected, would greatly increase yield. Therefore studying some cultural practice which may affect on shedding is very essential such as planting dates, fertilization and fertilizers splitting. In this respect Miley et al. (1969) reported that nutrients deficiency during the stages of flowering and fruiting may reduce cotton boll retention, which results in decreased yields. Varma (1982) indicated that Nitrogen is an important nutrient that prevents abscission of squares and bolls. Turnip seed et al. (1995). Found that early sowing produced significantly more squares than late sown ones. Perumal (1999) reveald that increasing nitrogen level significantly increased squares formation. Ali and El-sayed (2001) observed that delaying cotton planting date reflected inversely on most of flowering and boll opening as well as boll shedding. Anjum et al. (2007) revealed that increased nitrogen to cotton may result in more accumulation of photosynthetic assimilates that resulted in higher fruit weight. Arshad et al. (2007) showed that, early sowing produced $10 \%$ more flowers, $23 \%$ more open bolls and 18\% more seed cotton yield. Loka and Oosterhuis (2010) showed that high temperatures are considered to be one of the main environmental factors contributing in lowered yields for cotton and this has been attributed to a negative effect on respiration and carbohydrate accumulation. Said (2011) studied splitting applied of NPK fertilizers, he found that number of flowers, number of open bolls, boll weight and seed cotton yield per fed, tended to be increased as number of partitioning fer- tilizers was increased. These results may be due to the low leaching of such fertilizers. Moreover, splitting may help cotton plants to face its requirement through the different stages of growth. Rosolem et al. (2013) found that higher temperatures increased the fruit abscission. Abd ElAal (2014) showed that increasing mineral $\mathrm{N}$ level reduced boll shedding percentage. Echer et al. (2014) indicated that increasing night temperature during the floral bud and flowering stages increased the flower production rates per plant However, this increase did not result in a greater number of reproductive structures because the rate of abortion also increased. Shoaib et al. (2015) found that late planting led to decrease seed cotton yield and its components, i.e. number of bolls/ plant and boll weight. Loka and Oosterhuis (2016) indicated that high night temperature had an immediate effect on leaf respiration rates and membrane damage by significantly increasing them and a similar pattern was observed on leaf photosynthesis and ATP levels that were markedly decreased, and it was concluded that high night temperatures had a negative effect on cotton flower bud production due to disruptions on flower bud carbohydrate metabolism.

The objective of this investigation was to determine the influence of some cultural practices on shedding and yield of Egyptian cotton Giza- 90 cultivar in Upper Egypt (Shandaweel Agric. Res. Sta., Sohage Governorate).

\section{Material and Methods}

Two field experiments were carried out at Shandaweel Agric. Res. 
Sta., Agric. Res. Centre, Sohage Governorate, Egypt, during the two growing seasons of 2013 and 2014 to study effect of some cultural practices on shedding and yield of Egyptian cotton cultivar Giza 90 (Gossypiumbarbadense L.). Separate experiments were devoted for each planting date; the variables in each experiment were distributed as split plot design with four replications. Where the fertilization rates were allotted in the main plots and fertilizers splitting were arranged in the sub- plots. The treatments were as follows:

A- Sowing date (time):

1) Normal sowing date on $20^{\text {th }}$ March.

2) Late sowing date on $20^{\text {th }}$ April.

B- N\&K fertilizer level swith application of micronutrients foliar:

1) $50+24 \mathrm{~kg}$ N\&K $/$ fed.

2) $50+24 \mathrm{~kg} \mathrm{N \& K} /$ fed. + Spray micronutrients $(200 \mathrm{~g} / \mathrm{fed}$.).

3) $70+36 \mathrm{~kg} \mathrm{N \& K} /$ fed.

4) $70+36 \mathrm{~kg} \mathrm{~N} \& \mathrm{~K} /$ fed. + Spray micronutrients $(200 \mathrm{~g} / \mathrm{fed}$.).
Here, it should be noted that nitrogen fertilization in the form of ammonium nitrate $(33 \% \mathrm{~N})$ was applied, potassium fertilizer was applied as potassium sulphate $\left(48 \% \mathrm{~K}_{2} \mathrm{O}\right)$ and micronutrients (Fe, $\mathrm{Zn}, \mathrm{Mn}$ and $\mathrm{B}$ ) were in forms EDTA (Chelating) and applications were two sprays in the bloom stage as follows; First spray was at the beginning of flowering, second spray was after the first spray by two weeks.

C- The splitting of N\&K treatments:

1). Two equal parts before the second and third irrigation ( $\mathrm{Sp} 2)$.

2). Three equal parts before the second, the third and the fourth irrigation (Sp3).

3). Four equal parts before the second, third, fourth and fifth irrigations ( $\mathrm{Sp} 4)$.

The mechanical and chemical analyses of the soil at the experimental site in Shandaweel agricultural research station are shown in Table (1), Chapman and Pratt (1978).

Table 1. Mechanical and chemical analysis of soil samples for the experimental site in 2014 and 2015 seasons.

\begin{tabular}{|c|c|c|c|c|c|c|c|c|c|c|}
\hline \multicolumn{11}{|c|}{ Mechanical analysis } \\
\hline Season & Clay $(\%)$ & Silt (\%) & \multicolumn{2}{|c|}{ Sand (\%) } & \multicolumn{3}{|c|}{ Organic matter (\%) } & \multicolumn{3}{|c|}{ Texture class } \\
\hline 2014 & 30.60 & 50.40 & \multicolumn{2}{|c|}{19.00} & \multicolumn{3}{|c|}{1.86} & \multirow{2}{*}{\multicolumn{3}{|c|}{ Silt clay loam }} \\
\hline 2015 & 32.25 & 49.29 & \multicolumn{2}{|c|}{18.46} & \multicolumn{3}{|c|}{1.79} & & & \\
\hline \multicolumn{11}{|c|}{ Chemical analysis } \\
\hline \multirow{2}{*}{ Season } & \multirow{2}{*}{ ph } & \multirow{2}{*}{$\begin{array}{c}\text { EC } \\
(\mathbf{m m} / \mathbf{c m}) \\
\end{array}$} & \multirow{2}{*}{$\begin{array}{c}\mathrm{Ca} \mathrm{CO}_{3} \\
(\%)\end{array}$} & \multicolumn{7}{|c|}{ Available element (ppm) } \\
\hline & & & & $\mathbf{N}(\%)$ & $\mathbf{P}$ & $\mathbf{K}$ & $\mathrm{Fe}$ & B & $\mathbf{Z n}$ & Mn \\
\hline 2014 & 7.56 & 1.02 & 2.75 & 0.58 & 6.21 & 287 & 9.21 & 0.63 & 1.67 & 4.82 \\
\hline 2015 & 7.63 & 0.96 & 2.42 & 0.49 & 6.85 & 266 & 8.50 & 0.71 & 1.55 & 5.31 \\
\hline
\end{tabular}

Phosphorus in the form of ordinary calcium supe-phosphate $(15.5 \%$ P205) was applied through land preparation at the rate of $22.5 \mathrm{~kg} \mathrm{P}_{2} \mathrm{O}_{5} /$ fed. The size of each plot was $10.5 \mathrm{~m}^{2}$ (including five ridges each of $0.70 \mathrm{~m}$ width $\times 3 \mathrm{~m}$ long) and the distance between hills was $25 \mathrm{~cm}$. Here, it should be noted that the preceding crop was tomato (Solanumlycopersi- 
cum) in 2014 season and pepper (Capsicum annuum) in 2015 season.

In both seasons, the two outer ridges were let as a border. Random samples of six plants were chosen from the three inner ridges of each sub-plot, in order to study the following traits; Total number of squares/plant, total number of flowers/plant, shedding percentage of squares, shedding percentage of bolls, number of open bolls/plant, boll weight $(\mathrm{g})$ and the yield of seed cotton in kentar/fed, (One Kentar = $157.5 \mathrm{~kg}$.).

The combined analysis for data from the two planting dates was carried out in eachyear for all previously mentioned characters according to Gomez and Gomez (1984). Significant means of any trait studied were compared using, Least significant difference (L.S.D) at 5\% probability level according to Waller and Duncan (1969).

\section{Results}

\section{Planting dates effect:}

Data recorded in Tables $(2 \& 7)$ revealed a significant differences between $20^{\text {th }}$ March and $20^{\text {th }}$ April planting dates for all studied trait in 2014 and 2015 seasons. The favorable date produced greater mean values than the latter in each of number of squares, number of flowers, number of opening bolls, boll weight and seed cotton yield/fed in both seasons. Reversible trend was shown as for shedding $\%$ either in squares or bolls. Which showed a marked increase in favor of April planting date in 2014 and 2015 season.

\section{Fertilizer rates effect:}

Tables (2\&7) exhibitedsignificant differences among fertilization rates as for all studied traits in 2014 and 2015 season. High fertilization rate, i.e. $70 \mathrm{~kg} / \mathrm{N}+36 \mathrm{~kg} / \mathrm{K}_{2} \mathrm{O}$ and $70 \mathrm{~kg} / \mathrm{N}+36 \mathrm{~kg} / \mathrm{K}_{2} \mathrm{O}+$ micronutrients sprayed, produced the maximum values for all the studied traits (number of squares, number of flowers, shedding of squares, number of opening bolls, boll weight and seed cotton yield/fed), except, shedding bolls \% which decreased when fertilization quantities were increased in both growing season.

\section{Fertilizers Splitting effect:}

Split of fertilizers had a significant effect on all the studied traits in both seasons. The data in Tables (2\&7) proved that all the studied characters tended to be increased as number of partitioning fertilizers was increased during the both seasons of study. The maximum values of squares number, flowers number, squares shedding, opening bolls number, boll weight and seed cotton yield/fed, were observed in splitting of fertilizers into 4 equal partitions. Reversible trend was shown as for bolls shedding where it tended to be decreased as number of splitting fertilizers was increased, but it was a slight decrease.

\section{Interaction effect:}

The first order interaction, i.e. planting date $\mathrm{x}$ fertilizers rates was significant for the most of studied traits, i.e. number of squares, number of flowers, number of open bolls, boll weight and seed cotton yield/fedin favor of early planting on March for the two seasons, Tables (3\&8). While, the interaction showed that the higher fertilizer during late planting caused a great shedding in squares and bolls compared with the same 
treatments in early planting in both season (Table 3). The first order interaction, i.e. planting date $\mathrm{x}$ splitting fertilizers was significant for all the traits except, bolls shedding and boll weight which were not significant in the two seasons Tables (4\&9). The interaction indicated that late sown plants have a lower response to splitting than early sown ones. The interaction showed too that splitting ferti- lizers during late planting caused a great loss in squares than splitting the same rates of fertilizers in early planting. Here too, all studied traits did not significantly affected by either fertilization ratesx fertilizers splitting or planting dates $\mathrm{x}$ fertilization rates $\mathrm{x}$ fertilizers splitting interactions in both seasons, except number of squares per plant in 2015 and 2014 seasons, respectively.

Table 2. Cotton shedding attributes as affected by sowing dates, fertilization and fertilizers splitting during 2014 and 2015 seasons.

\begin{tabular}{|c|c|c|c|c|c|c|c|c|c|}
\hline \multirow{2}{*}{\multicolumn{2}{|c|}{ Treatment }} & \multicolumn{2}{|c|}{ No. of squares/plant } & \multicolumn{2}{|c|}{$\begin{array}{c}\text { No. of flow- } \\
\text { ers/plant }\end{array}$} & \multicolumn{2}{|c|}{$\begin{array}{c}\text { Square shedding } \\
(\%)\end{array}$} & \multicolumn{2}{|c|}{$\begin{array}{c}\text { Boll shedding } \\
(\%)\end{array}$} \\
\hline & & 2014 & 2015 & 2014 & 2015 & 2014 & 2015 & 2014 & 2015 \\
\hline \multirow{2}{*}{ planting ates } & First date & 154.64 & 150.37 & 45.08 & 39.73 & 70.68 & 73.1 & 41.58 & 45.91 \\
\hline & Second date & 143.29 & 131.59 & 28.55 & 24.93 & 79.65 & 80.87 & 49.27 & 49.17 \\
\hline \multicolumn{2}{|c|}{ F-test } & $* *$ & $* *$ & $* *$ & $* *$ & $* *$ & $* *$ & $* *$ & $* *$ \\
\hline \multirow{4}{*}{ Fertilization } & $\mathbf{A}$ & 128.5 & 119.97 & 33.60 & 29.75 & 73.92 & 75.36 & 47.17 & 52.35 \\
\hline & $\mathbf{B}$ & 130.41 & 122.33 & 33.85 & 30.41 & 74.12 & 75.34 & 46.99 & 52.08 \\
\hline & $\mathbf{C}$ & 166.83 & 159.66 & 39.56 & 34.35 & 76.28 & 78.61 & 43.69 & 44.00 \\
\hline & D & 170.12 & 161.95 & 40.24 & 34.80 & 76.35 & 78.73 & 43.86 & 41.71 \\
\hline \multicolumn{2}{|c|}{ LSD at 0.05} & 3.70 & 3.90 & 0.68 & 0.65 & 0.65 & 0.65 & 0.74 & 1.74 \\
\hline \multirow{3}{*}{$\begin{array}{l}\text { Fertilizers } \\
\text { Splitting }\end{array}$} & 2 doses & 134.65 & 128.68 & 35.20 & 30.42 & 73.79 & 76.27 & 45.90 & 48.70 \\
\hline & 3 doses & 148.43 & 142.76 & 37.06 & 32.67 & 75.03 & 77.10 & 45.70 & 47.55 \\
\hline & 4 doses & 163.81 & 151.5 & 38.17 & 33.88 & 76.68 & 77.66 & 44.67 & 46.36 \\
\hline \multicolumn{2}{|c|}{ LSD at 0.05} & 2.64 & 2.88 & 0.56 & 0.62 & 0.51 & 0.57 & 0.83 & 1.83 \\
\hline
\end{tabular}

\section{Where:}
A) $50+24 \mathrm{~kg} \mathrm{~N} \& \mathrm{~K} /$ fed.
B) $50+24 \mathrm{~kg} \mathrm{~N} \& \mathrm{~K} /$ fed. + Spray micronutrients ( $200 \mathrm{~g} /$ fed.).
C) $70+36 \mathrm{~kg} \mathrm{~N} \& \mathrm{~K} / \mathrm{fed}$.
D) $70+36 \mathrm{~kg} \mathrm{N \& K} /$ fed. + Spray micronutrients $(200 \mathrm{~g} /$ fed.).

Table 3. Cotton shedding attributes as affected by interaction between sowing dates and fertilization rates during 2014 and 2015 seasons.

\begin{tabular}{|c|c|c|c|c|c|c|c|c|c|}
\hline \multicolumn{2}{|c|}{ Treatment } & \multicolumn{2}{|c|}{ No. of squares/plant } & \multicolumn{2}{|c|}{ No. of flowers/plant } & \multicolumn{2}{|c|}{$\begin{array}{c}\text { Square shedding } \\
\%\end{array}$} & \multicolumn{2}{|c|}{$\begin{array}{c}\text { Boll shedding } \\
\%\end{array}$} \\
\hline $\begin{array}{c}\text { Planting } \\
\text { dates }\end{array}$ & Fertilization & 2014 & 2015 & 2014 & 2015 & 2014 & 2015 & 2014 & 2015 \\
\hline \multirow{4}{*}{ First date } & $\mathbf{A}$ & 135.58 & 125.5 & 41.08 & 36.75 & 69.62 & 70.64 & 43.45 & 51.00 \\
\hline & B & 140.33 & 130.58 & 41.83 & 37.48 & 70.12 & 71.08 & 43.90 & 51.89 \\
\hline & $\mathrm{C}$ & 169.33 & 170.5 & 48.29 & 41.45 & 71.41 & 75.57 & 39.20 & 41.47 \\
\hline & D & 173.33 & 174.91 & 49.11 & 43.23 & 71.58 & 75.24 & 39.76 & 39.26 \\
\hline \multirow{4}{*}{ Second date } & $\mathbf{A}$ & 121.41 & 114.45 & 26.12 & 22.75 & 78.23 & 80.09 & 50.88 & 53.71 \\
\hline & $\mathbf{B}$ & 120.50 & 114.08 & 25.86 & 23.33 & 78.12 & 79.51 & 50.07 & 52.27 \\
\hline & $\mathbf{C}$ & 164.33 & 148.83 & 30.83 & 27.25 & 81.15 & 81.65 & 48.18 & 46.52 \\
\hline & D & 166.91 & 149.00 & 31.37 & 26.37 & 81.12 & 82.22 & 47.95 & 44.17 \\
\hline \multicolumn{2}{|c|}{ LSD at 0.05} & 5.23 & 5.52 & 0.97 & 0.92 & 0.93 & 0.93 & 1.05 & 2.47 \\
\hline
\end{tabular}


Table 4. Cotton shedding attributes as affected by interaction between sowing dates and fertilizers splitting during 2014 and 2015 seasons.

\begin{tabular}{|c|c|c|c|c|c|c|c|c|c|}
\hline \multicolumn{2}{|c|}{ Treatment } & \multicolumn{2}{|c|}{ No. of squares/plant } & \multicolumn{2}{|c|}{ No. of flowers/plant } & \multicolumn{2}{|c|}{$\begin{array}{c}\text { Square shedding } \\
\%\end{array}$} & \multicolumn{2}{|c|}{$\begin{array}{c}\text { Boll shedding } \\
\%\end{array}$} \\
\hline Planting dates & Fertilizers Splitting & 2014 & 2015 & 2014 & 2015 & 2014 & 2015 & 2014 & 2015 \\
\hline \multirow{3}{*}{ First date } & 2 doses & 142.06 & 135.06 & 43.05 & 37.30 & 69.60 & 72.04 & 41.81 & 48.04 \\
\hline & 3 doses & 155.12 & 152.12 & 45.31 & 40.22 & 70.65 & 73.20 & 41.80 & 45.92 \\
\hline & 4 doses & 166.75 & 163.93 & 46.87 & 41.67 & 71.79 & 74.24 & 41.14 & 43.76 \\
\hline \multirow{3}{*}{ Second date } & 2 doses & 127.25 & 122.31 & 27.36 & 23.56 & 78.00 & 80.50 & 50.00 & 49.35 \\
\hline & 3 doses & 141.75 & 133.40 & 28.81 & 25.12 & 79.42 & 81.01 & 49.61 & 49.18 \\
\hline & 4 doses & 160.87 & 139.06 & 29.48 & 26.10 & 81.60 & 81.09 & 48.21 & 49.00 \\
\hline \multicolumn{2}{|c|}{ LSD at 0.05} & 3.74 & 4.08 & 0.79 & 0.87 & 0.72 & 0.81 & N.S & N.S \\
\hline
\end{tabular}

Table 7. Cotton yield and yield components as affected by sowing dates, fertilizationratesand fertilizers splitting during 2014 and 2015 seasons.

\begin{tabular}{|c|c|c|c|c|c|c|c|}
\hline \multirow{2}{*}{\multicolumn{2}{|c|}{ Treatment }} & \multicolumn{2}{|c|}{ No. of bolls/plant } & \multicolumn{2}{|c|}{ Boll weight (g) } & \multicolumn{2}{|c|}{ Seed cotton yield /fed. } \\
\hline & & 2014 & 2015 & 2014 & 2015 & 2014 & 2015 \\
\hline \multirow{2}{*}{ planting dates } & First date & 26.40 & 21.71 & 2.01 & 2.31 & 11.04 & 10.07 \\
\hline & Second date & 14.54 & 12.74 & 1.94 & 2.03 & 7.16 & 6.79 \\
\hline \multicolumn{2}{|c|}{ F- test } & $* *$ & $* *$ & $* *$ & $* *$ & $* *$ & $* *$ \\
\hline \multirow{4}{*}{ Fertilization } & $\mathbf{A}$ & 18.07 & 14.28 & 1.86 & 2.10 & 8.26 & 7.87 \\
\hline & B & 18.18 & 14.60 & 1.93 & 2.11 & 8.64 & 8.02 \\
\hline & $\mathbf{C}$ & 22.67 & 19.44 & 2.04 & 2.21 & 9.53 & 8.83 \\
\hline & D & 22.96 & 20.58 & 2.07 & 2.26 & 9.97 & 9.01 \\
\hline \multicolumn{2}{|c|}{ LSD at 0.05} & 0.40 & 0.71 & 0.02 & 0.06 & 0.36 & 0.27 \\
\hline \multirow{3}{*}{$\begin{array}{l}\text { Fertilizers Split- } \\
\text { ting }\end{array}$} & 2 doses & 19.43 & 15.74 & 1.95 & 2.11 & 8.85 & 8.23 \\
\hline & 3 doses & 20.49 & 17.40 & 1.99 & 2.18 & 9.10 & 8.45 \\
\hline & 4 doses & 21.48 & 18.53 & 1.99 & 2.22 & 9.35 & 8.61 \\
\hline \multicolumn{2}{|c|}{ LSD at 0.05} & 0.38 & 0.77 & 0.03 & 0.04 & 0.33 & 0.17 \\
\hline
\end{tabular}

Table 8. Cotton yield and yield components as affected by interaction between sowing dates and fertilization rates during 2014 and 2015 seasons.

\begin{tabular}{|c|c|c|c|c|c|c|c|}
\hline \multicolumn{2}{|c|}{ Treatment } & \multicolumn{2}{c|}{ No. of bolls/plant } & \multicolumn{2}{c|}{ Boll weight (g) } & \multicolumn{2}{c|}{ Seed cotton yield /fed. } \\
\hline Planting dates & Fertilization & $\mathbf{2 0 1 4}$ & $\mathbf{2 0 1 5}$ & $\mathbf{2 0 1 4}$ & $\mathbf{2 0 1 5}$ & $\mathbf{2 0 1 4}$ & $\mathbf{2 0 1 5}$ \\
\hline \multirow{4}{*}{ First date } & $\mathbf{A}$ & 23.22 & 18.00 & 1.87 & 2.27 & 9.88 & 9.30 \\
\cline { 2 - 8 } & $\mathbf{B}$ & 23.45 & 18.08 & 1.96 & 2.30 & 10.48 & 9.54 \\
\cline { 2 - 8 } & $\mathbf{C}$ & 29.35 & 24.29 & 2.07 & 2.34 & 11.53 & 10.50 \\
\cline { 2 - 8 } & $\mathbf{D}$ & 29.58 & 26.43 & 2.14 & 2.33 & 12.28 & 10.96 \\
\hline \multirow{4}{*}{ Second date } & $\mathbf{A}$ & 12.91 & 10.54 & 1.86 & 1.93 & 6.63 & 6.44 \\
\cline { 2 - 8 } & $\mathbf{B}$ & 12.92 & 11.12 & 1.89 & 1.92 & 6.80 & 6.49 \\
\cline { 2 - 8 } & $\mathbf{C}$ & 15.98 & 14.50 & 2.00 & 2.08 & 7.52 & 7.15 \\
\cline { 2 - 8 } & $\mathbf{D}$ & 16.33 & 14.73 & 2.01 & 2.19 & 7.67 & 7.06 \\
\hline \multicolumn{2}{|c|}{ LSD at $\mathbf{0 . 0 5}$} & $\mathbf{0 . 5 7}$ & $\mathbf{1 . 0 1}$ & $\mathbf{0 . 0 3}$ & $\mathbf{0 . 0 9}$ & $\mathbf{0 . 5 1}$ & $\mathbf{0 . 3 9}$ \\
\hline
\end{tabular}

Table 9. Cotton yield and yield components as affected by interaction between sowing dates and fertilizers splitting during 2014 and 2015 seasons.

\begin{tabular}{|c|c|c|c|c|c|c|c|}
\hline \multicolumn{2}{|c|}{ Treatment } & \multicolumn{2}{c|}{ No. of bolls/plant } & \multicolumn{2}{c|}{ Boll weight (g) } & \multicolumn{2}{c|}{ Seed cotton yield /fed. } \\
\hline Planting dates & Fertilizers Splitting & $\mathbf{2 0 1 4}$ & $\mathbf{2 0 1 5}$ & $\mathbf{2 0 1 4}$ & $\mathbf{2 0 1 5}$ & $\mathbf{2 0 1 4}$ & $\mathbf{2 0 1 5}$ \\
\hline \multirow{3}{*}{ First date } & $\mathbf{2 ~ d o s e s}$ & 25.10 & 19.48 & 1.98 & 2.26 & 10.57 & 9.73 \\
\cline { 2 - 8 } & $\mathbf{3 ~ d o s e s}$ & 26.43 & 21.97 & 2.03 & 2.32 & 11.05 & 10.12 \\
\cline { 2 - 8 } & $\mathbf{4}$ doses & 27.67 & 23.67 & 2.02 & 2.36 & 11.51 & 10.37 \\
\hline \multirow{3}{*}{ Second date } & $\mathbf{2}$ doses & 13.76 & 12.00 & 1.92 & 1.96 & 7.14 & 6.73 \\
\cline { 2 - 8 } & $\mathbf{3 ~ d o s e s}$ & 14.55 & 12.84 & 1.95 & 2.04 & 7.14 & 6.77 \\
\cline { 2 - 8 } & $\mathbf{4 ~ d o s e s}$ & 15.29 & 13.40 & 1.95 & 2.08 & 7.20 & 6.86 \\
\hline \multicolumn{2}{|r|}{ LSD at 0.05 } & $\mathbf{0 . 5 4}$ & $\mathbf{1 . 1 0}$ & N.S & N.S & $\mathbf{0 . 4 7}$ & $\mathbf{0 . 2 5}$ \\
\hline
\end{tabular}




\section{Discussion}

Data recorded in Table (2) indicated significant differences between $20^{\text {th }}$ March and 20th April planting dates. The former produced greater mean values than the latter in each of squares and flowers. Reversible trend was shown in shedding \%, either in shed of squares or bolls, as they showed marked increase in favor of April planting date. Regarding the seed cotton yield and yield components, i.e. number of bolls/plant and boll weight. Here too data recorded in Table (7) revealed that significant differences between $20^{\text {th }}$ March and $20^{\text {th }}$ April planting dates. The former produced greater mean values than the latter in each of previously mentioned characters. The results clearly indicated that the growth and development of cotton plants were favored by early planting on March. The present results are in harmony with those obtained by Bibiet al.(2008); Arevalo et al.(2008); Loka and Oosterhuis.(2010) and Rosolem et al.(2013) who, showed that delaying planting date makes plants emergence at a disadvantage for photosynthesis, where high temperature above the optimum will increase the oxidation and consequently decrease the accumulation of the total soluble carbohydrates in plants, which, would lead to increases abscission and leading to significant lower in yield. In this report, boll retention decreases significantly under late sowing where high temperatures Ali and El-sayed (2001) and Rosolem et al.(2013), as well as boll number and boll size, the basic yield components, are negatively impacted by high temperature Zhao et al.(2005); Ali and El-sayed. (2001) and Ali et al. (2015). Since the number of bolls and boll weight were decreased as well as increasing the shedding $\%$ in the late planting Deho et al.(2014); Ali et al.(2010) and Arshadet al. (2007). It could be expected that seed cotton yield will decrease Shoaib et al. (2015); Huang (2015) and Ali et al.(2015).

Tables ( 2 \&7) indicated significant differences among the quantities of fertilizers. The highest rate of fertilizers led to high increase in studied characters, i.e. number of squares, number of flowers, number of bolls/plant, boll weight and finally the seed cotton yield/fed. Micronutrients spray didn't show any reaction at most of studied characters and its effects ranged from non-existent to a slight effects on some characters. This is could be expected since the soil analysis Table (1) showed that the experimental soil was rich in these nutrients. In general these results might be explained on the base, that increasing $\mathrm{N}$ levels up to $70 \mathrm{~kg} /$ fed addition to $36 \mathrm{~kg} /$ fed of $\mathrm{K}_{2} \mathrm{Ogave}$ cotton plants its requirements from nutrients which provides squares, flowers and the small formed bolls Munir et al.(2015); Sagar et al.(2014) and Abd El-Aal.(2014). Resulting in more setting of bolls and decreasing the shedding of bolls/plant Abd ElAal.(2014) and Bismillah and Shabbir (2006), which reflected on seed cotton yield/fed Sagar el al.(2014); Abd ElAal.(2014) and Munir et al. (2015). It should be noted that, with high fertilization, boll shedding was decreased, while a reversible trend was shown in the squares shedding. This may be due to competition on nutrients, where heavy boll load may cause in- 
creased abscission, as well as bolls are stronger sinks than squares and young bolls, therefore are better able to compete for available nutrients Matthews (1979).

The results in Tables $(2 \& 7)$ showed that the fertilizer splitting had a significant effect on all traits, i.e. number of squares, flowers, bolls/plant, boll weight and seed cotton yield / fed. All values of mentioned characters tended to be increased, as number of partitioning fertilizers was increased. This return to, splitting fertilizers may decrease the leaching and to face the requirements of cotton plant during the different stages of growth Said (2011) and improved nutrients use efficiencies Raju et al. (2008). Therefore, maximum of yield at harvest Alagudurai et al.(2006) and Gawade et al.(2014), where any deficiency of nutrients during the stages of flowering and fruiting may reduce cotton boll retention, which results in decreased yield Miley et al.(1969).

Conclusion: Early planting (March) and splitting the higher fertilization rates into four equal doses can help cotton plants to escape from high shedding and obtained high yield.

\section{References}

Abd El-Aal, A.S. (2014). Effect of some plant densities patterns and nitrogen fertilizer rates on cotton yield, its components and fiber properties of hybrid cotton 10229 X Giza 86 under early and late sowing. J. Plant Prod., Mansoura Univ., 5(7): 12391258.

Alagudurai, S.; M. Premsekhar; K. Pushpanathan and D. Kumar
(2006). Influence of nitrogen levels and its time of applications on yield and quality parameters of hybrid cotton. Madras J. Agric., 93(1-6): 119-121.

Ali, H; M.N. Afzal; S. Ahmad; D. Muhammad; Z. Hasnain; R. Perveen and M.H. Kazmi (2010). Quantitative and qualitative traits of (Gossypiumhirsutum L.) as affected by agronomic practices, Journal of Food, Agriculture \& Environ., 8 (3\&4): 945-948.

Ali, L.; M. Ali, M. UdDin, L. Khalid, U. Kalsoom, M. Waqar, M. Ali and M. Sattar (2015). Growth and yield of two cotton varieties as affected by various planting dates. International J. of Advanced Multidisciplinary Res., 2(8):71-80.

Ali, S.A. and A.E. El- Sayed (2001). Effect of sowing dates and nitrogen levels on growth, earliness and yield of Egyptian cotton cultivar Giza 88. Egypt . J. Agric. Res., 79(1):22 - 232.

Anjum, F.; A. Tanveer; R. Ahmad; A. Ali; M. Nadeem and M. Tahir (2007). Response of cotton (GossypiumhirsutumL.) to split application of nitrogen and weed control methods. Indian J. Agric. Sci., 77(4): 224-229.

Arevalo, L.M.; D.M. Oosterhuis; D.L. Cocker and R.S. Brown (2008). Physiological response of cotton to high night temperatures. Am. J. Plant Sci., Biotech. 2: 63-68.

Arshad, M.; A. Wajid; M. Maqsood; K. Hussain; M. Aslam and M. Ibrahim (2007). Response of growth, yield and quality of dif- 
ferent cotton cultivars to sowing dates. Pak. J. Agric., 44(2): 208212.

Bibi, A.C.; D.M. Oosterhuis and E.G. Gonias (2008). Photosynthesis quantum yield of photosystem II, and membrane leakage as affected by high temperatures in cotton genotypes. J. Cotton Sci., 12: $150-159$.

Bismillah, M. and J. Shabbir (2006). Response of cotton (GossypiumhirsutrumL.) cultivars to different level of nitrogen. J. Res. Sci., 17(4): 257-261.

Chapman, H.D. and P.P. Pratt.(1978). Methods of analysis for soils plants and water. Univ. of California, Div. of Agric. Sci., Priced Publ. 4034.

Deho, Z.; S. Tunio; Q. Chachar and F. Oad (2014). Impact of sowing dates and picking stages on yield and seed maturity of cotton (Gossypiumhirsutum L.) Varieties. Sarhad J. of Agric., 30 (4): 404-410.

Echer, F. R., D. M. Oosterhuis; D. A. Loka and C. A. Rosolem(2014). High Night Temperatures During the Floral Bud Stage Increase the Abscission of Reproductive Structures in Cotton, $\mathrm{J}$ Agro Crop Sci ISSN 0931-2250, 191-198.

Gawade, R.T.; S.R. Imade; B.A. Gudade and M.R. Thakur (2014). Effect of fertilizer doses and split application of nitrogen and potassium on productivity, profitability and quality of bt. cotton (GossypiumhirsutumL.) under rained conditions Ecology. Environ and Conservation Paper Supplement Issue, Dec.,: 67-70.
Gomez, K.A. and A.A. Gomez (1984).Statistical procedures for agriculture research. $2^{\text {nd }}$ Ed., John Willey and Sons, New York, USA.

Huang, J. (2015). Effects of meteorological parameters created by different sowing dates on drip irrigated cotton yield and yield components in Arid Regions in China. J. Horticulture., 2: 163.

Loka, D.A. and D.M. Oosterhuis (2010). Effect of high night temperatures on cotton respiration, ATP levels and carbohydrate content. Environ. Exp. Bot., 68: 258-263.

Loka, D.A. and D.M. Oosterhuis (2016). Increased night temperatures during cotton's early reproductive stage affect leaf physiology and flower bud carbohydrate content, decreasing flower bud retention, J Agron Crop Sci; ISSN 0931-2250.

Matthews, M.A. (1979). Effects of shedding in cotton on carbohydrate partitioning in adjacent fruiting position, M.Sc. Thesis, In the Graduate College., Univ. of Arizona, USA.

Miley, W.N.; G.W. Hardy; M.B. Sturgis and F.E. SedberryJr (1969). Influence of boron, nitrogen and potassium on yield, nutrient uptake and abnormalities of cotton. J. Agron. 61: 913.

Munir, M.; M.Tahir; M. Saleem and M. Yaseen (2015). Growth, yield and earliness response of cotton to row spacing and nitrogen management. J. Anim. Plant Sci., 25(3): 729-738. 
Perumal, N.K. (1999). Effect of different nitrogen levels on morpho-physiological characters and yield in rainfed cotton. Indian J. of Plant Physic., 4(1): 65-67.

Raju. A. R.; Pundareekakshudu, R.; Majumdar, G.; Uma, B (2008).Split application of N, P, $\mathrm{K}, \mathrm{S}$ and foliar spray of DAP in rainfedhirsutum cotton, Journal o soils and crop, Vol. 18 No. 2 pp. 305-316.

Rosolem, C.A.; D.M. Oosterhuis and F.S. Souza (2013). Cotton response to mepiquat chloride and temperature, Sci. J. Agric., 70 (2): 82-87.

Sagar, D.; R. Balikai and D. Biradar (2014). Influence of varied dosages of nitrogen application on the leafhopper population in $\mathrm{Bt}$ cotton under rainfed condition. Res. of Crops, 15(2): 498-502.

Said, M. T. (2011). Physiological response of Egyptian cotton to some cultural practices in Assiut governorate. Ph.D.Thesis, Fac. Agric., Assiut University, Eygpt.

Shoaib, M.; A. Salah; A. Razique; M. Jamil; M. Yousaf; A. N.Shah; N. Shah; A. Bakhsh and M. Ba- loch (2015). Influence of different planting scheduling and cultivar on the growth and yield of cotton crop. J. of Bio.Agric. and Healthcare.5 (1).

Turnipseed, S.G., Mann, J.E., Sullivan, M.J. and DuRant, J.A. (1995). Loss of early season fruiting sites: Should we reexamine as pest - management strategies change. Proc. Belt. Cotton Conf., National Cotton Council, Memphis TN, pp. 821823.

Varma, S. K. (1982). Endogenous nitrogen content in flower buds and bolls of cotton (Gossypiumhirsutum L.) in relation to abscission. Agric. Sci. Dig. India 2, 113-115.

Waller, R.A. and D.B. Duncan (1969). A bays rule for the symmetric multiple comparison problem. J. Amer. Stat. Assoc., 1485-1503.

Zhao, D.; K. Reddy; V. Kakani; S. Koti and W. Gao (2005). Physiological causes of cotton fruit abscission under conditions of high temperature and enhanced ultraviolet-B radiation. Physiol. Plant, 124: 189-199. 


\section{تأثير بعض العمليات الزراعيه علي التساقط والمحصول في القطن المصري

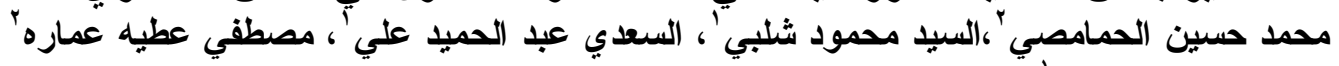

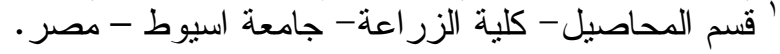

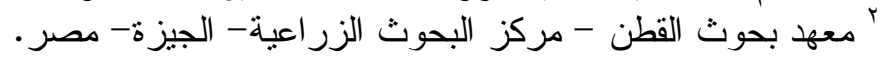

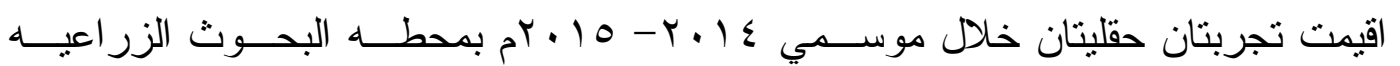
الملخص

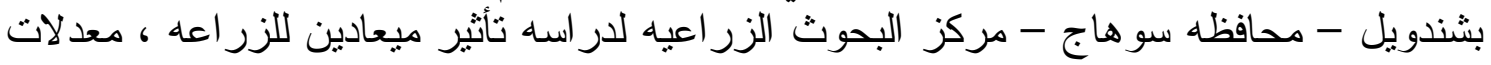

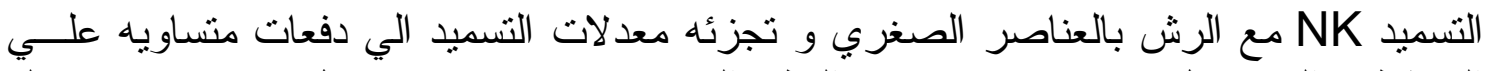

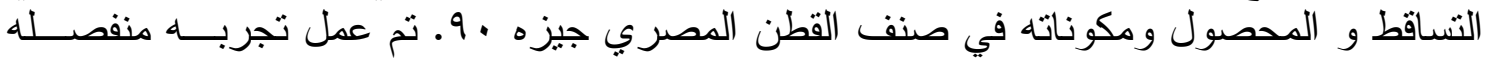

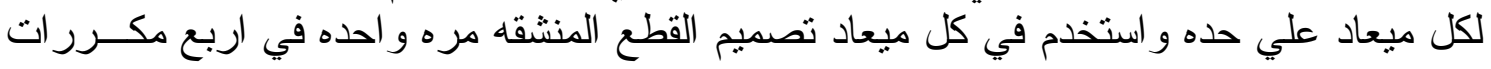

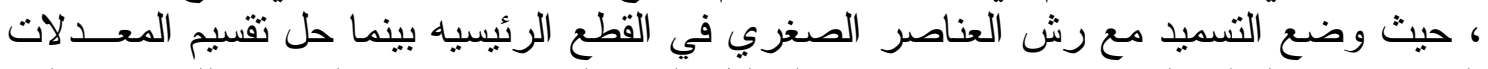

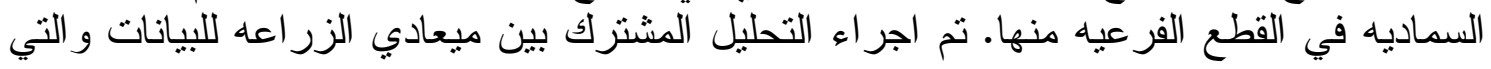
يمكن عرض الهم نتائجها في النقاط التاليه:

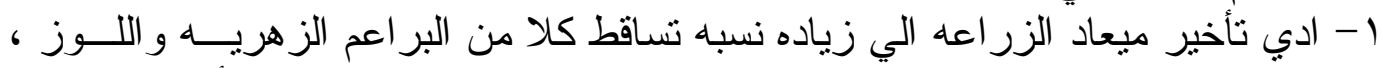

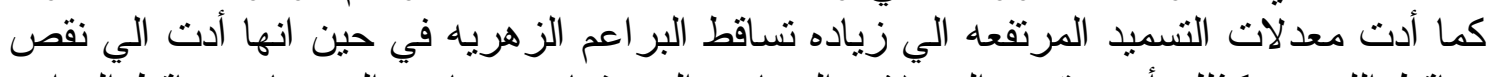

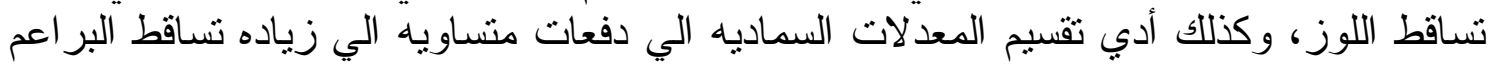
الزهريه وخفض تساقط اللوز

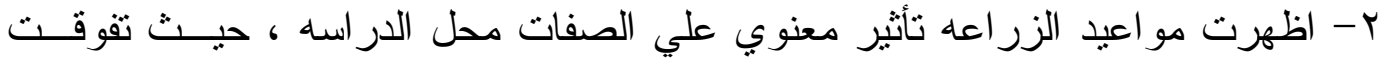

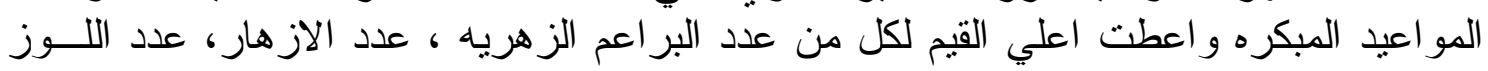
المتفتح ، وزن اللوزه للنبات ومحصول اعلى اعلي الفدان في كلا الموسمين.

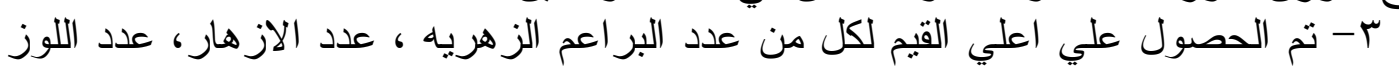

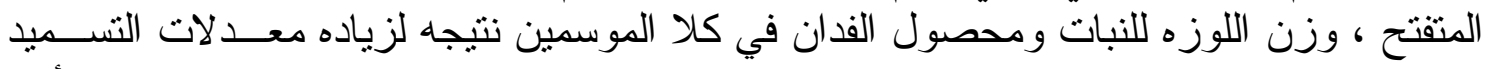

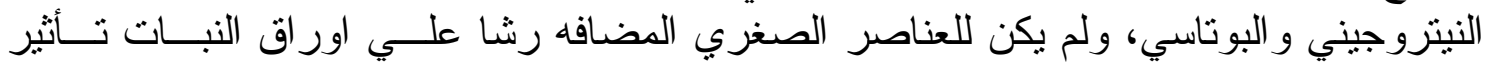
و اضح علي معظم الصفات.

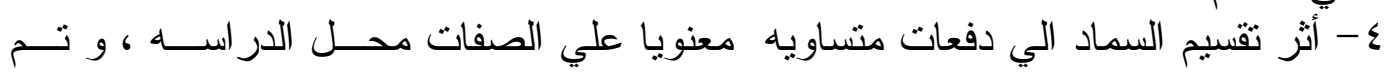

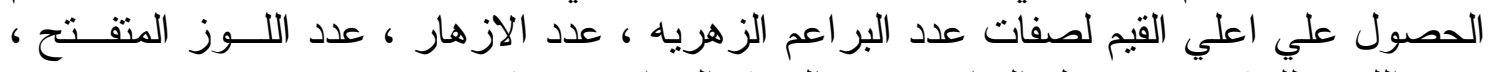

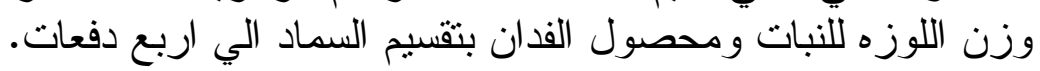

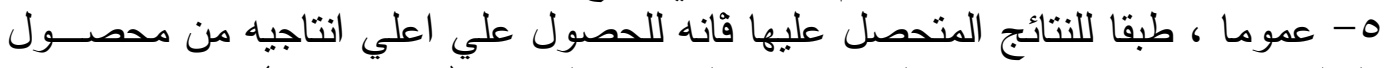

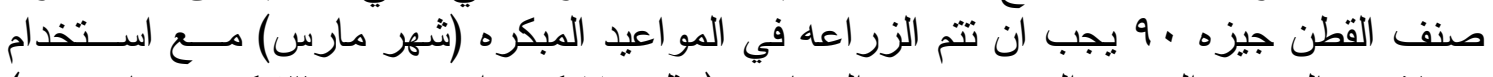

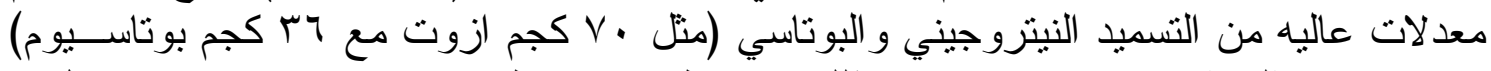

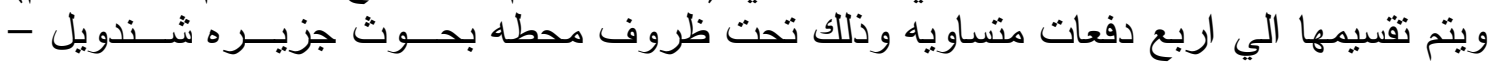
محافظه سو هاج. 